\title{
Факторна структура фізичної та функціональної підготовленості студентів з порушенням постави
}

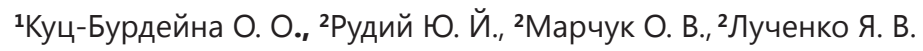 \\ ${ }^{1}$ Вінницький соціально-економічний інститут Університету «Україна», м. Вінниця, Україна \\ ${ }^{2}$ Вінницький національний медичний університет ім. М. І. Пирогова, м. Вінниця, Україна
}

\begin{abstract}
Актуальність. Порушення постави $є$ одним із чинників, який негативно впливає на функціональні можливості організму, а також сприяє виникненню деяких хронічних захворювань. Розповсюдженість порушень постави у студентів зумовлена складністю організації роботи, відсутністю оптимальних методик фізичного виховання у закладах вищої освіти та низькою мотивацією молоді до занять фізичною культурою.
\end{abstract}

Мета дослідження: дослідити факторну структуру функціональної підготовленості студентів-юнаків 3 порушенням постави.

Матеріали та методи дослідження. Обстежено 108 юнаків віком від 17 до 21 року з порушенням постави. При проведенні факторного аналізу використовувалась закрита модель методу головних компонентів. Ротацію референтних осей здійснено за допомогою Веримакс-критерію.

Результати дослідження та їх обговорення. У студентів 3 порушенням постави показники фізичної та функціональної підготовленості виявилися вірогідно гіршими, ніж у студентів 3 нормальною поставою. Результати факторизації показників підготовленості юнаків 3 порушенням та без порушення постави вказують на високий кореляційний зв'язком між фізичною та функціональною підготовленістю. У студентів 3 порушенням постави вправи повинні спрямовуватись на розвиток витривалості - близько $35 \%$; вправи для вдосконалення анаеробних можливостей - близь- ко $27 \%$. Зважаючи на досить високу дисперсію (11\%) від загальної вибірки силової статичної витривалості м'язів, які підтримують поставу, необхідно включати в програму навантажень вправи для підвищення тонусу постуральних м'язів; вправи для розвитку силової статичної витривалості м'язів спини та сідничних м'язів мають складати близько $23 \%$.

Висновки. Порушення постави є досить поширеною патологією, яка зустрічається у студентів вищих навчальних закладів і негативно впливає на їх фізичну та функціональну підготовленість. Отримані результати факторного аналізу дозволяють розробити програму занять 3 фізичного виховання, які матимуть безпосередній вплив на показники фізичної працездатності, максимального споживання кисню та анаеробних можливостей організму для забезпечення ефективності процесу занять фізичними вправами.

Перспективи подальших досліджень. Планується дослідження факторної структури фізичної та функціональної підготовленості студентів з різними типами постави.

Ключові слова: факторна структура, порушення постави, студенти.

Конфлікт інтересів: значимість факторів у структурі відображає необхідність удосконалення фізичної та функціональної підготовленості студентської молоді з порушенням постави, однак відсотковий внесок показників потребує диференційованого підходу. 